\title{
Efficiency of an Innovative Didactic Approach in Graphic Design Teaching
}

\author{
Matjaž Duh ${ }^{1}$ and Martina Kač Nemanič ${ }^{2}$ \\ 'University of Maribor, Faculty of Education \\ ${ }^{2}$ University of Primorska, Faculty of Design
}

\section{Abstract}

Modern educational methods enable the development of pupils' creative design expression, but the role and importance of the didactic approaches in secondary schools have not been thoroughly researched. The paper presents the research results regarding the influence of an innovative didactic approach from the point of view of the development of art design creativity and artistic knowledge in graphic design teaching. The differences were monitored among pupils in the 3rd year of secondary school (age 17-18) in Slovenia. We have confirmed positive effects in favour of the experimental group, as a result of a set of didactic decisions, namely the combination, diversity and dynamics of teaching methods, teaching forms and didactic communication. The positive effects of the experimental approach show that the introduction of minor methodological changes can significantly improve the development of artistic creativity and artistic knowledge. By introducing the basic ideas of the innovative didactic approach (Duh, 2004), we have confirmed the effectiveness, flexibility and subtlety of innovation at the level of secondary school. We also found that the experimental program was suitable for both girls and boys, and that it could be implemented in various social environments.

Keywords: artistic creativity; high school; teaching methods; teaching forms; didactic communication

\section{Introduction}

Modern world trends in schools are primarily oriented towards didactic approaches with an active, creative, diverse and dynamic way of learning and teaching (Terhart, 2001). The effectiveness of education is also largely dependent on the teacher's choice of 
teaching methods, teaching forms and didactic communication, which influence students' activity, motivation and learning (Duh, 2004). By using modern teaching methods, the teaching and learning process is adapted to the needs and developmental possibilities of individual students, while encouraging curiosity and intrinsic motivation. In addition to the general methods, Karlavaris $(1987,1991)$ mentions specific learning methods, which can be adapted to the methodological particularities and characteristics of graphic design lessons. The supposition of contemporary art didactics is that, in addition to general methods of work, it is reasonable to include specific methods in order to achieve active creative work in pedagogical practice (Duh, 2004; Herzog, 2013; Duh \& Zupančič, 2013), i.e. methods that emphasize the importance of specific teaching methods in achieving educational goals and promoting creativity. The possibilities of combination and the diversity of learning methods and forms also contribute to the dynamics of the learning process, its attractiveness, adaptation to the distinct learning styles of students and consideration of their individual needs (Blažičc, 2003; Lamagna \& Selim, 2005; Strmčnik, 1999). "Dynamic changing and interweaving of individual learning methods stimulates students to visualize the evaluation criteria, to discuss the criteria and compare them to the exhibited works of art" (Duh, 2004, p. 193).

Of utmost importance in lesson planning is the quality of the interactioncommunication activity between the teacher and the student (Littlejohn \& Foss, 2007). Sincerity, uniformity and symmetry of didactic communication help create a relaxed atmosphere and help students to actively create and evaluate their own artistic efforts. The knowledge of evaluation criteria enables easier development of the ability to evaluate and be critical. With creative, open communication that is goal oriented, direct, clear, responsible, positive, honest, attentive and cooperative, students can enjoy the process of designing as an integral part of the learning process (Brajša, 1993; Duh, 2004).

Many contemporary researchers agree on the importance of incorporating creativity in school, despite the diversity of definitions, criteria and approaches to promoting creativity in science and art (Hennessey \& Amabile, 2010; Flint, 2014). Craft (2003) also argues that creativity is an important component of education, while Williams and Askland (2012, p. 9) emphasize the strong connection between design and creativity: "designing is a discipline that searches for balance between form and function, originality and practicality, novelty and appropriateness". They add that creativity is an integral part of designing, design processes and education (ibidem). However, despite these findings, authors Ehmann (2005) and Alhajri (2013) point to the limited amount of research in the field of graphic design didactics, a lack which is also confirmed by Tudor (2008), who believes that the study of learning approaches in the field of graphic design is not given enough attention. The experts who have studied the connection between education and the development of creativity (Hewett et al., 2005; Supek, 1987; Karlavaris \& Kraguljac, 1981; Kvaščev, 1976; Vygotsky, 1978) agree that creativity can be developed and promoted by appropriate didactic approaches, which is confirmed by researchers in the field of design didactics (Hsiao \& Lin, 2004; Lau, 2009). When 
scrutinizing creativity, we find that some authors define the notion of creativity as a creative product, a creative process, personality characteristics of the creator, and the interaction of the individual with the environment (Plucker \& Renzulli, 1999; Stevanović, 2002; Trstenjak, 1981). Other researchers have different opinions on the choice of creativity criteria in the field of design: product, process or personality traits (Ellmers, 2006; Ehmann, 2005). Nevertheless, they mostly agree that the creative product can be defined by the elements of novelty and relevance (Atkinson, 2000 Howard et al., 2008; Howard-Jones, 2002). The creativity of the product is assessed on the basis of originality, transformation and ability to find changes that lead to solving a problem in a new, innovative way.

Modern lessons include the development of diverse student skills in acquiring knowledge. However, learning does not mean only the acquisition of knowledge, skills and habits, but is a progressive change of an individual based on their own activity, when the existing knowledge is linked to a new one (Ferjan, 2003). Given the purpose, goals and task types of Art lessons, the solving of problems is inextricably connected to the creative dimension of personality, while their resolution activates not only cognitive but also social, motivational, emotional, intuitive and psychomotor abilities (Karlavaris, 1991; Berce Golob, 1990; Tomić, 2003; Duh, 2004). The teacher can motivate students by using appropriate methods of work and influence their activity so that they process the information, the development of thinking and the acquisition of artistic knowledge with interest and curiosity (Pranjić, 2005). In classes of graphic design, the teacher also directs the students to learn about artistic concepts by way of artistic problem planning, since direct experience of an artistic problem promotes better perception, memory and linking of the artistic knowledge. The students, on the basis of their own visual experience of a direct environment or artistic work, develop artistic thinking, which they relive and express in the design product, thus acquiring new artistic knowledge. Gagné (1984) argues that students should be gradually, intentionally and systematically directed to master conceptual artistic knowledge, retain it in memory, and thus independently use and upgrade it with new knowledge. Effective teaching offers students a variety of forms and methods for acquiring knowledge in the artistic field, depending on the type of knowledge and learning aims: from a strict system oriented toward the teaching content to the method of free research, where students independently change topics and learn actively with their own construction process (Spiro et al., 1987).

The development of aesthetic experience is connected to the emotional part of the personality, since it involves the formation of personal attitudes towards the beauty of a certain observed object or phenomenon; it is also determined by the social framework, which is influenced by the cultural-socio-historical features of the environment, which dictates taste and trends in what is considered beautiful (Kroflič, 2007). Methods of adopting and expressing aesthetics are created gradually. The ability to perceive is in the foreground, then accepting and experiencing beauty, which is followed by assessment, interpretation and the ability to create (Malić \& Mužić, 1990). In graphic design classes, students gradually perceive what is "beautiful"; in the process of 
appreciation, the teacher gradually leads them through the process of observing and accepting the presented designs. With the development of appreciation, the students acquire an aesthetic experience, which is followed by their own perception and mental processing of the experience (Duh, 2014). A teacher with a dynamically based learning approach can develop a level of aesthetic judgment in the students, in the form of a personal interpretation of an artistic problem. One of the key aims of aesthetic development of students is a form of creation in which students "assert themselves as creative personalities and add their personal contribution to the aesthetic one" (Malić \& Mužić, 1990, p. 178).

The results of research at the elementary school level showed that an innovative didactic approach with a dynamic, diverse combination of learning methods, forms and didactic communication has a positive effect on artistic development, as well as creativity, knowledge and appreciation abilities (Duh, 2004). At the level of secondary school, we also find a positive effect on the development of artistic appreciation (Kač Nemanič, 2017) and artistic creativity (Duh \& Kač Nemanič, 2018). At both levels, however, the effect of an innovative didactic approach with tests that are envisaged for a specific area of design has not been explored. Research into the impact of introducing an innovative approach presents a special challenge both for teachers of artistic subjects and for researchers, who are trying to create an active, interesting, creative and dynamically designed graphic design lesson through minor didactic changes.

\section{Empirical research}

\section{Defining the research problem and a brief presentation of the content of the set of didactic decisions in a pedagogical experiment}

The study focused on monitoring the influence of an innovative didactic approach on the development of artistic skills, which was supervised through artistic creativity, knowledge of fine arts and the capacity for aesthetic assessment in students from the 3rd year of secondary school (age 17-18) in Slovenia. The innovative approach contained a set of didactic decisions, which represented minor changes in the existing program, and thus did not influence the content of the program. It contains interweaving, dynamics and diversity of methodological procedures, namely combinations of learning methods, learning forms and relevant didactic communication, which are characteristic of certain phases of teaching. We also strived for a clear set of evaluation criteria and consistent formative and summative evaluation.

\section{Purpose and objectives of the research}

The aim of the empirical research is to monitor the development of creativity among third-year secondary school students in Slovenia. We sought to establish the following:

- Differences in the artistic development, the level of artistic creativity, acquired knowledge and the ability to aesthetically assess between the experimental group, with an innovative way of learning and teaching, and a group with a regular way of learning and teaching. 
- Progress at the artistic level, the level of artistic creativity, acquired knowledge, and the ability to assess aesthetically by gender.

- Progress at the artistic level, the level of artistic creativity, acquired knowledge, and the ability to assess aesthetically according to the region.

\section{Research hypotheses}

The planning of the research is based on the following research hypotheses. First, we formed the hypotheses relating to the differences between the experimental and the control group:

$\mathrm{H1}$ : Students in the experimental group will show a higher level of artistic skill after the experiment is finished, compared to students in the control group.

H1.1: Students in the experimental group will show a higher level of artistic creativity after the experiment is finished, compared to students in the control group.

H1.2: Students in the experimental group will show a higher level of artistic knowledge after the experiment is finished, compared to students in the control group.

$\mathrm{H} 1.3$ : Students in the experimental group will show a higher level of aesthetic assessment after the experiment is finished, compared to students in the control group.

Hypotheses related to gender:

$\mathrm{H} 2$ : The level of progress in artistic skills as the result of the innovative didactic approach in the experimental group will not differ according to gender.

$\mathrm{H} 2.1$ : The level of progress in artistic creativity as the result of the innovative didactic approach in the experimental group will not differ according to gender.

H2.2: The level of progress in artistic knowledge as the result of the innovative didactic approach in the experimental group will not differ according to gender.

$\mathrm{H} 2.3$ : The level of progress in aesthetic assessment as the result of the innovative didactic approach in the experimental group will not differ according to gender.

Hypotheses related to region :

H3: The level of progress in artistic skill as the result of the innovative didactic approach in the experimental group will not differ according to region: the Osrednjeslovenska, Podravska and Pomurska regions.

H3.1: The level of progress in artistic creativity as the result of the innovative didactic approach in the experimental group will not differ according to region: the Osrednjeslovenska, Podravska and Pomurska regions.

H3.2: The level of progress in artistic knowledge as the result of the innovative didactic approach in the experimental group will not differ according to region: the Osrednjeslovenska, Podravska and Pomurska regions.

H3.3: The level of progress in the capacity for aesthetic assessment as the result of the innovative didactic approach in the experimental group will not differ according to region: the Osrednjeslovenska, Podravska and Pomurska regions. 


\section{Methodology}

\section{Research method}

For the purpose of the study, the experimental method of traditional empiricalanalytical pedagogical research was used.

\section{Research sample}

To obtain answers to the questions asked, 73 randomly selected students in the 3rd year (17-18 years) from three secondary schools in the Osrednjeslovenska, Podravska and Pomurska regions were included.

\begin{tabular}{lcccc}
$\begin{array}{l}\text {l} \begin{array}{l}\text { Table } 1 \\
\text { Demographic data }\end{array} \\
\text { Region }\end{array}$ & KS N (\%) $\mathrm{n}=35$ & $\begin{array}{c}\mathrm{ES} \mathrm{N}(\%) \\
\mathrm{n}=38\end{array}$ & $\chi 2$ & $\mathrm{P}$ \\
\hline Ljubljana & $13(17.8 \%)$ & $12(16.4 \%)$ & 0.25 & 0.88 \\
Maribor & $11(15.1 \%)$ & $13(17.8 \%)$ & & \\
Murska & $11(15.1 \%)$ & $13(17.8 \%)$ & & \\
Sobota & & & & \\
\hline Gender & & & & \\
Boys & $20(27.4 \%)$ & $16(21.9 \%)$ & 1.65 & 0.20 \\
Girls & $15(20.5 \%)$ & $22(30.1 \%)$ & & \\
\hline
\end{tabular}

The sample comprised 36 boys (49.3\%) and 37 girls (50.7\%). The research included 25 (34.2\%) students from Ljubljana, 24 students from Maribor and 24 students (32.9\%) from Murska Sobota secondary school. There were 38 students in the experimental group $(52.1 \%)$ and 35 students in the control group (47.9\%). We used the Chi-square test to check differences beetwen gender and region, because the potential differences would have influenced the final result.

\section{Course of research and instrumentation}

Data acquisition began by testing the students in both groups. We used a test called LN-LKD to measure the development of artistic skills in the design area (Karlavaris, 1981; Duh, 2004), which was followed by a period of experimental work: lessons with the innovative didactic approach were carried out in the experimental group, and regular lessons in the control group. The experiment was performed during regular classes of graphic design and included all such secondary schools in Slovenia. In the experimental group, the teaching was carried out under the usual working conditions over a range of 14 didactic units, and was constantly interlinked and intertwined with the introduction of a set of innovative didactic decisions. After the experiment was completed, the level of artistic creativity was again reviewed by testing, with the LNLKD test in the experimental and control group. The LN-LKD in numerous studies partly or entirely (Berce Golob, 1990; Duh, 2004; Duh \&Herzog, 2011; Duh \& Matrić, 2015; Herzog, 2009; Karlavaris \& Kraguljac, 1981) showed the appropriate measurement characteristics (validity, reliability, objectivity and sensitivity). The adequacy from the 
point of view of reliability was confirmed in this study, where the value of the Cronbach's alpha reliability coefficient ( $\alpha$ ) for the total score of Creativity is 0.81 , Knowledge 0.85 , Aesthetics 0.67 and Artistic Abilities 0.792.

Nine tasks were selected for the LN-LKD test, with which we monitored the students' development of artistic skills in the field of design. The first set of tasks was designed to monitor the development of artistic creativity, then artistic knowledge and visual aesthetics. The students could achieve 0-8 points in each task, the total sum thus being 72 points.

Table 2

Presentation of the LN-LKD test

\begin{tabular}{|c|c|c|}
\hline & Tasks & Abilities \\
\hline Creativity 1 & $\begin{array}{l}\text { Visualization of similar shapes in } \\
\text { design based on motifs from nature. }\end{array}$ & $\begin{array}{l}\text { Suitability of transforming a "natural" } \\
\text { construction into a design. }\end{array}$ \\
\hline Creativity 2 & $\begin{array}{l}\text { Defining the appropriate dimensions } \\
\text { of elements from different materials. }\end{array}$ & $\begin{array}{l}\text { Ability to define dimensions by } \\
\text { considering the characteristics of } \\
\text { materials. }\end{array}$ \\
\hline Knowledge 3 & $\begin{array}{l}\text { Distinction between sculpture and } \\
\text { design, verbal definition. }\end{array}$ & $\begin{array}{l}\text { Defining the characteristics of two } \\
\text { artistic disciplines. }\end{array}$ \\
\hline Knowledge 4 & $\begin{array}{l}\text { Distinction between an industrial and } \\
\text { unique design, specification of the } \\
\text { characteristics of both areas. }\end{array}$ & $\begin{array}{l}\text { Defining the characteristics of } \\
\text { industrial and unique design. }\end{array}$ \\
\hline Knowledge 5 & $\begin{array}{l}\text { Selective election of features relevant } \\
\text { for the quality of the designer } \\
\text { solution. }\end{array}$ & $\begin{array}{l}\text { Ranking of the features required for } \\
\text { the quality of the designer solution. }\end{array}$ \\
\hline Knowledge 6 & $\begin{array}{l}\text { Differentiation of the characteristics } \\
\text { of two types of differently designed } \\
\text { designer works based on a graphic } \\
\text { template. }\end{array}$ & $\begin{array}{l}\text { Identification of the characteristics } \\
\text { of two types of differently designed } \\
\text { designs. }\end{array}$ \\
\hline Aesthetics 7 & $\begin{array}{l}\text { Identifying the conformity of } \\
\text { elements of design products. }\end{array}$ & Recognition of aesthetic value. \\
\hline Aesthetics 8 & $\begin{array}{l}\text { Creative redefinition of a designer } \\
\text { form into a sculptural one. }\end{array}$ & $\begin{array}{l}\text { Suitability of the transformation of } \\
\text { the design product in accordance } \\
\text { with aesthetic principles. }\end{array}$ \\
\hline Aesthetics 9 & $\begin{array}{l}\text { Visual aesthetic analysis of the } \\
\text { artwork. }\end{array}$ & $\begin{array}{l}\text { Recognizing the artistic aesthetic } \\
\text { value of the artwork. }\end{array}$ \\
\hline
\end{tabular}

\section{Data processing}

For the purpose of the study, we used the experimental method of empirical-analytical pedagogical research and the following statistical procedures:

- descriptive result statistics (frequencies - f, percentage - \%, sample size - N);

- Shapiro-Wilk test for determining the normality of distribution of results;

- Mann-Whitney U-test for determining differences in the results of individual tasks and overall values between the control and the experimental group, and the study of the role of gender at the level of the overall results of the development of artistic skills, the level of artistic creativity, the acquired knowledge and the ability to perform aesthetic assessment. The result of the analysis showed that 
the distribution of the results of the pedagogical experiment for individual and overall values in view of the groups was not normal, since the calculated value of the statistical significance is lower than the limit $\mathrm{p}<0.05$;

- Kruskal-Wallis test for determining the role of region at the level of overall results for the development of artistic skills, the level of artistic creativity, the acquired knowledge and the ability to perform aesthetic assessment. The result of the analysis showed that the distribution of the results of the pedagogical experiment for individual and overall values in view of the groups was not normal, since the calculated value of the statistical significance is lower than the limit $\mathrm{p}<0.05$.

The data were processed using the SPSS computer program for statistical data processing.

\section{Results and interpretation Analysis of the initial state}

Below we present the analysis of the differences between students in the experimental and the control group on individual tasks, and at the level of the overall results before the experiment. The Mann-Whitney experiment was used.

Table 3

The results of the Mann-Whitney U-test between groups before the experiment

\begin{tabular}{|c|c|c|c|c|c|c|c|}
\hline & & Mean ranks & Mean ranks & $\begin{array}{c}\text { Mann } \\
\text { Whitney }\end{array}$ & & & $\begin{array}{l}\text { Effect } \\
\text { size }\end{array}$ \\
\hline & & $\mathrm{MR}(\mathrm{ES})$ & $\mathrm{MR}(\mathrm{KS})$ & $U$ & $P$ & Z & $R$ \\
\hline 1 & Creativity & 36.88 & 36.88 & 660.50 & 0.912 & -0.10 & 0.01 \\
\hline 2 & Creativity & 37.95 & 37.95 & 629.00 & 0.400 & -0.83 & 0.10 \\
\hline 3 & Knowledge & 33.72 & 33.72 & 540.50 & 0.081 & -1.71 & 0.20 \\
\hline 4 & Knowledge & 34.66 & 34.66 & 576.00 & 0.192 & -1.30 & 0.15 \\
\hline 5 & Knowledge & 35.22 & 35.22 & 597.50 & 0.332 & -0.95 & 0.11 \\
\hline 6 & Knowledge & 36.17 & 36.17 & 636.00 & 0.652 & -0.44 & 0.05 \\
\hline 7 & Aesthetics & 36.18 & 36.18 & 634.00 & 0.474 & -0.71 & 0.08 \\
\hline 8 & Aesthetics & 39.08 & 39.08 & 586.00 & 0.223 & -1.21 & 0.14 \\
\hline \multirow[t]{6}{*}{9} & Aesthetics & 36.79 & 36.79 & 657.00 & 0.874 & -0.16 & 0.02 \\
\hline & Total & & & & & & \\
\hline & Creativity & 37.93 & 37.93 & 629.50 & 0.543 & -0.60 & 0.07 \\
\hline & Knowledge & 33.11 & 33.11 & 517.00 & 0.094 & -1.66 & 0.19 \\
\hline & Aesthetics & 38.14 & 38.14 & 621.50 & 0.571 & -0.55 & 0.06 \\
\hline & Artistic abilities & 36.41 & 37.64 & 642.50 & 0.801 & -0.25 & 0.03 \\
\hline
\end{tabular}

In monitoring the differences between the groups in the initial state, the students were fairly equal at the level of the development of artistic skills, checked through artistic creativity, demonstrated knowledge and the ability to perform aesthetic assessment in individual tasks as well as the overall results. The results of the Mann Whitney experiment $(\mathrm{U}=642.50, \mathrm{p}=0.801, \mathrm{r}=0.03)$ showed that among the students of the experimental group $(M R=36.41)$, there were no statistically significant differences 
in the overall development of artistic skills compared to the control group students $(\mathrm{MR}=37.64)$ at the level of artistic skill development in the initial state.

\section{Final state analysis}

When the experimental work, which occupied 14 didactic units, was completed, the final tests were carried out. We re-examined the differences in individual tasks and at the level of overall results in the experimental and the control group.

In the final state, we found statistically significant differences $(p \leq 0.05)$ on all individual tasks in the group with the innovative approach (ES).

In the first two sets of tasks, the students appropriately visualized similar forms in a design based on motifs from nature (Creativity 1 ). Thus, they showed various creative abilities where redefinition as a factor of creativity was crucial for the success of the design: to make something new from something familiar or given. The result can be largely attributed to the use of specific artistic methods (Duh, 2004), which thus proved to be relevant not only for the field of general art, but also for the field of design.

Table 4

Results of the Mann-Whitney U-test between groups in the final state

\begin{tabular}{llcccccc}
\hline & $\begin{array}{c}\text { Mean } \\
\text { ranks }\end{array}$ & $\begin{array}{c}\text { Mean } \\
\text { ranks }\end{array}$ & $\begin{array}{c}\text { Mann } \\
\text { Whitney }\end{array}$ & & & $\begin{array}{c}\text { Effect } \\
\text { size }\end{array}$ \\
\hline & MR(ES) & MR(KS) & U & P & Z & R \\
\hline 1 & Creativity & 43.14 & 30.33 & 431.50 & 0.000 & -2.94 & 0.34 \\
2 & Creativity & 41.39 & 32.23 & 498.00 & 0.050 & -1.94 & 0.23 \\
3 & Knowledge & 42.57 & 30.96 & 453.50 & 0.011 & -2.41 & 0.28 \\
4 & Knowledge & 41.39 & 32.23 & 498.00 & 0.050 & -1.94 & 0.23 \\
5 & Knowledge & 45.63 & 27.63 & 337.00 & 0.000 & -3.87 & 0.45 \\
6 & Knowledge & 53.53 & 19.06 & 37.00 & 0.000 & -7.52 & 0.88 \\
7 & Aesthetics & 44.36 & 29.01 & 385.50 & 0.000 & -3.59 & 0.42 \\
8 & Aesthetics & 47.41 & 25.70 & 269.50 & 0.000 & -4.80 & 0.56 \\
9 & Aesthetics & 48.78 & 24.21 & 217.50 & 0.000 & -5.70 & 0.67 \\
& Total & & & & & & \\
& Creativity & 43.92 & 29.49 & 402.00 & 0.000 & -3.04 & 0.35 \\
& Knowledge & 52.46 & 20.21 & 77.50 & 0.000 & -6.08 & 0.71 \\
& Aesthetics & 53.33 & 19.27 & 44.50 & 0.000 & -6.59 & 0.77 \\
& Artistic abilities & 54.37 & 18.14 & 5.00 & 0.000 & -7.29 & 0.85 \\
\hline
\end{tabular}

The performance of the students on the next set of tasks (Knowledge 3, 4, 5 and 6 ) is not surprising. We allow the possibility that teachers with adequate didactic communication succeeded in additionally stimulating students to acquire knowledge. Sincere, equal, equivalent and empathic communication between students and teachers is often decisive for students to acquire the required knowledge, with the imaginative and interesting approach of the teacher in situ being an important factor. For acquiring knowledge during the pedagogical experiment, we sometimes used group learning methods and pair work, and not just the individual form of learning, since teamwork can be more effective compared to work on an individual basis (Pibernik et al., 2010). 
The students had no major problems solving the tasks in the third set (Aesthetics 7,8 and 9). They successfully recognized the uniformity of the elements based on a given design theme and creatively redefined the designer product into a sculptural one, and in our opinion, the clearly defined evaluation criteria, as well as the formative and the summative evaluation, were the contributing factor. The students were also successful in recognizing the artistic aesthetic value of the artwork. We allow the possibility of interpreting that the thoughtful course of appreciation, by including all phases of observation and acceptance of art works, contributed positively to the aesthetic development of the students.

The results of the Mann Whitney experiment $(U=5.00, P=0.000, r=0.85)$ regarding the overall development of artistic abilities showed that students in the experimental group (ES; $\mathrm{Mr}=54.37$ ) in the final state achieved a higher level of development of artistic abilities compared to the control group students (KS; $\mathrm{Mr}=18.14)$. The overall result for artistic creativity, the level of acquired knowledge and the ability to perform aesthetic assessment after the experiment were higher in the experimental group than the control group. Hypotheses H1, H1.1, H1.2 and H1.3 were thus confirmed (Table 4). By including an active way of learning and teaching in the innovative approach, we demonstrated a positive influence on the development of artistic abilities, artistic creativity, knowledge and the capaicty for aesthetic assessment with appropriate inclusion of specific learning methods (Duh, 2004; Karlavaris, 1987, 1991), diverse teaching methods (Meyer, 2005) and proper didactic communication (Littlejohn \& Foss, 2007; Duh, 2004). On the basis of findings by researchers in the development of creativity (Berce Golob 1990; Duh, 2004; Duh \& Herzog, 2011; Duh, Čagran \& Huzjak, 2012; Duh \& Matric, 2015; Duh, Herzog \& Lopert, 2017), we confirmed the positive influence of the innovative didactic approach and appropriateness of decoding, adaptation of teaching methods, learning forms and the use of didactic communication in graphic design classes in secondary school.

The second set of hypotheses with the LKD test for the field of design analysed the level of progress in artistic abilities, artistic creativity, achieved knowledge and aesthetic assessment ability in the experimental group according to gender.

\section{Analysis of the initial state}

Table 5

Results of Mann-Whitney U-test of the initial overall results of development in artistic abilities, artistic creativity, knowledge and aesthetic assessment ability in the experimental group according to gender

\begin{tabular}{lcccccc}
\hline & Mean ranks & Mean ranks & Mann Whitney & & & Effect size \\
\hline & MR(girls) & MR(boys)p & U & P & Z & r \\
\hline Creativity & 21.11 & 17.28 & 140.50 & 0.120 & -1.55 & 0.25 \\
Knowledge & 20.52 & 18.09 & 153.50 & 0.493 & -0.67 & 0.11 \\
Aesthetics & 20.80 & 17.72 & 147.50 & 0.314 & -0.99 & 0.16 \\
Total & & & & & & \\
Artistic abilities & 16.06 & 22.00 & 121.00 & 0.101 & -1.64 & 0.27 \\
\hline
\end{tabular}


When monitoring the role of gender in the development of artistic abilities, the acquired knowledge and the ability to perform aesthetic assessment, we found that there were no statistically significant differences between boys and girls. The results of the Mann Whitney experiment $(\mathrm{U}=121.00, \mathrm{P}=0.101, \mathrm{r}=0.27)$ showed that the level for male students $(M R=16.06)$ and female students $(M R=22,00)$ in overall results for the development of artistic ability in the experimental group in the final state showed no statistically significant difference according to gender.

\section{Final state analysis}

Table 6

Results of Mann-Whitney U-test of final overall results for development in artistic ability, artistic creativity, knowledge and aesthetic assessment ability in the experimental group according to gender

\begin{tabular}{lcccccc}
\hline & $\begin{array}{c}\text { Mean } \\
\text { ranks }\end{array}$ & $\begin{array}{c}\text { Mean } \\
\text { ranks }\end{array}$ & $\begin{array}{c}\text { Mann } \\
\text { Whitney }\end{array}$ & & \multicolumn{2}{c}{$\begin{array}{c}\text { Effect } \\
\text { size }\end{array}$} \\
\hline MR(boys) & MR(girls) & U & P & Z & r \\
\hline Creativity & 14.75 & 14.75 & 100.00 & 0.020 & -2.32 & 0.38 \\
Knowledge & 18.47 & 18.47 & 159.50 & 0.601 & -0.51 & 0.08 \\
Aesthetics & 19.94 & 19.94 & 169.00 & 0.823 & -0.22 & 0.04 \\
Total & & & & & & 0.17 \\
Artistic abilities & 17.31 & 17.31 & 141.50 & 0.292 & -1.03 & 0.17 \\
\hline
\end{tabular}

When monitoring the role of gender in the development of artistic abilities, acquired knowledge and aesthetic assessment ability, we found that there were no statistically significant differences between boys and girls. Hypotheses H2, H2.2 and H2.3 were thus confirmed. However, in regards to the development of artistic creativity, we did find statistically significant differences in favour of girls. Hypothesis H2.1 was therefore not confirmed, in a result that could be expected. We allow the possibility of interpreting that, in view of the stronger emotional, affective component, girls intuitively succeeded in transforming the motif from nature into a design with greater success. The elaboration and sensitivity of girls as a factor in creativity also play an important role in the field of creativity.

The results of the Mann Whitney experiment $(\mathrm{U}=141.5, \mathrm{P}=0.292, \mathrm{r}=0.17)$ showed that overall results for the level of male students $(\mathrm{MR}=17.31)$ and female students $(\mathrm{MR}=21,09)$ on the development of artistic abilities among the experimental group in the final state showed no statistically significant differences according to gender. We find that the didactic approach is appropriate for both genders in terms of overall artistic development for girls and boys.

We then examined the set of hypotheses, where we analysed the level of progress in artistic abilities in the experimental group with respect to region. 


\section{Analysis of the initial state}

Table 7

Results of Kruskal-Wallis test on the initial overall results for overall development of artistic abilities, artistic creativity, knowledge and aesthetic assessment skill in the experimental group by region

\begin{tabular}{lcccccc}
\hline & Mean ranks & Mean ranks & Mean ranks & Kruskal Wallis & & Effect size \\
\hline & MR(LJ) & MR(MB) & MR(MS) & H & P & E $^{2}$ \\
\hline Creativity & 17.50 & 18.85 & 22.00 & 2.39 & 0.302 & 0.06 \\
Knowledge & 22.29 & 20.46 & 15.96 & 2.26 & 0.323 & 0.06 \\
Aesthetics & 20.83 & 16.96 & 20.81 & 1.44 & 0.484 & 0.04 \\
Total & & & & & & \\
Artistic abilities & 20.96 & 17.12 & 20.54 & 0.93 & 0.624 & 0.02 \\
\hline
\end{tabular}

When monitoring the role of region, we noted that there were no statistically significant differences at the level of achieved artistic creativity, acquired knowledge and the aesthetic assessment skills among students of the experimental group from all three secondary schools in the Osrednjeslovenska, Podravska and Pomurska regions. We also found that there were no differences with respect to region $(\mathrm{H}(2)=0.93$, $p=0.624)$, i.e. between students from the Osrednjeslovenska region $(M R=20.96)$, students of the Podravska region $(\mathrm{MR}=17,12)$ and students from the Pomurska region $(\mathrm{MR}=20.54)$ at the level of overall development of artistic abilities.

Table 8

Results of Kruskal-Wallis test on the final overall results for overall development of artistic abilities, artistic creativity, knowledge and aesthetic assessment skills in the experimental group by region

\begin{tabular}{lcccccc}
\hline & $\begin{array}{c}\text { Mean } \\
\text { ranks }\end{array}$ & $\begin{array}{c}\text { Mean } \\
\text { ranks }\end{array}$ & $\begin{array}{c}\text { Mean } \\
\text { ranks }\end{array}$ & $\begin{array}{c}\text { Kruskal } \\
\text { Wallis }\end{array}$ & $\begin{array}{c}\text { Effect } \\
\text { size }\end{array}$ \\
\cline { 2 - 7 } & MR(L) & MR(MB) & MR(MS) & H & $\mathrm{p}$ & $\mathrm{E}^{2}$ \\
\hline Creativity & 1950 & 23.12 & 15.88 & 2.93 & 0.232 & 0.08 \\
Knowledge & 24.67 & 16.08 & 18.15 & 4.42 & 0.101 & 0.12 \\
Aesthetics & 23.88 & 15.65 & 19.31 & 3.85 & 0.143 & 0.10 \\
Total & & & & & & \\
Artistic abilities & 22.33 & 18.35 & 18.04 & 1.15 & 0.560 & 0.03 \\
\hline
\end{tabular}

When monitoring the role of region, we noted that there were no statistically significant differences at the level of achieved artistic creativity, acquired knowledge and the aesthetic assessment skills among students of the experimental group from all three secondary schools in the Osrednjeslovenska, Podravska and Pomurska regions. We also found that there were no differences with respect to region $(\mathrm{H}(2)=1.15, \mathrm{p}$ $=0.560)$-i.e., between students from the Osrednjeslovenska region $(M R=22.33)$, students of the Podravska region $(\mathrm{MR}=18,35)$ and students from the Pomurska region $(\mathrm{MR}=18.04)$ at the level of overall development of artistic abilities. Thus, hypotheses 
H3, H3.1, H3.2 and H3.3 were confirmed. We found that region influenced neither the development of overall artistic abilities, nor the development of artistic creativity, knowledge and aesthetic assessment ability. Based on this result, we believe that the innovative approach to the development of artistic abilities as a phase in the educational process is suitable for implementation in varied social environments.

\section{Conclusion}

The experimental empirical-analytical study was conducted among third-year Slovenian secondary school students, aged 17-18, in graphic design classes on a non-random sample $(n=73)$. We examined the influence of an innovative didactic approach on the development of artistic skills in secondary school students. Monitoring of differences between the groups in the initial state showed that the groups were fairly consistent at the level of overall artistic abilities as well as on individual tasks. When monitoring the development of the overall values for artistic abilities, artistic creativity, knowledge in the field of fine arts and the aesthetic assessment ability, we found statistically significant differences in favour of the experimental group after the experiment was completed. The innovative approach thus had a favourable effect on the development of overall artistic abilities. We confirmed all the hypotheses in the first set (H1-H1.3). We also found a significant impact from the innovative didactic approach in artistic development, which is evidenced by the result of effect size $(r=0,853)$ in the final state.

After the experimental program, students in the experimental group developed more complex, subtle and creative artistic design abilities. The study (Duh, 2004), which examined the impact of the innovative didactic approach at the elementary level, also found a positive influence on general artistic creativity, artistic perception, artistic reception, artistic appreciation, art-creative development, artistic development and artistic creative-design development.

Furthermore, we tested the set of hypotheses related to the level of progress in artistic abilities, artistic creativity, knowledge in the field of fine arts and aesthetic assessment ability in the experimental group from the gender perspective. We confirmed the $\mathrm{H} 2$, H2.2 and H2.3 hypotheses; there are no statistically significant differences between boys and girls. Regarding the development of creativity, statistically significant differences were found in favour of girls. Hypothesis H2.1 was therefore not confirmed. Nevertheless, we find that the innovative didactic approach in the overall development of artistic abilities is appropriate for both genders. The results of the study regarding the influence of the innovative experimental program by Duh (2004) at the level of primary school also show that there are statistically insignificant differences between genders at the level of general artistic development.

In monitoring the role of region, we noted that there were no statistically significant differences in progress in artistic abilities, artistic creativity, knowledge in the field of fine arts, and aesthetic assessment ability in the experimental group among the students from the three regional secondary schools. Thus, hypotheses H3, H3.1, H3.2 
and $\mathrm{H} 3.3$ were confirmed. We can thus conclude that the experimental program can be implemented in varied social environments.

The results of the research show that Slovene secondary schools do not pay enough attention to promoting the development of artistic creativity with appropriate didactic approaches, which has been confirmed by research at the elementary level (Duh, 2004; Duh \& Herzog, 2011; Duh et al., 2017). Furthermore, the researchers note that there is little research in the field of didactic graphic design in conjunction with creativity (Ehmann, 2005; Alhajri, 2013) and that little attention is paid to the development of learning approaches in promoting creativity (Tudor, 2008). The results of this study show that it is possible to effectively, flexibly and subtly implement the concept of the innovative approach with a set of didactic decisions at the secondary school level, taking into account the characteristics of the discipline of graphic design and adapting to the level of development of each student. By introducing minor didactic changes, we can thus achieve essential progress in the development of artistic skills, artistic creativity, knowledge in the field of fine arts, and aesthetic assessment ability in secondary school graphic design classes.

\section{References}

Alhajri, S. A. S. (2013). Developing a pedagogical model to enhance and assess creativity in Omani graphic design education. (Doctoral dissertation). Loughborough University.

Atkinson, S. (2000). Does the need for High Levels of Performance Curtail the Devel-opment of Creativity in Design and Technology Project Work. International Journal of Design and Technology Education, 10(3), 255-281. https://doi.org/10.1023/A:1008904330356

Berce Golob, H. (1990). Metode likovno vzgojnega dela v osnovni šoli na področju slikarstva (Doctoral disertation). ALU.

Blažič, M. (2003). Učni mediji. In F. Strmčnik (Ed.), Didaktika, (pp. 257-329). Visokošolsko središče, Inštitut za raziskovalno in razvojno delo.

Craft, A. (2003). The Limits To Creativity In Education: Dilemmas For The Educator. British Journal of Educational Studies, 51(2), 113-127. https://doi.org/10.1111/1467-8527.t01-1-00229

Duh, M. (2004). Vrednotenje kot didaktični problem pri likovni vzgoji. Pedagoška fakulteta.

Duh, M. (2014). Razvijanje likovne apreciacije s srednješolci. Pedagoška obzorja, 29 (1), 60-75.

Duh M., \& Herzog J. (2011). Artistic and creative achievements of primary school students with regard to gender and stratum. Metodički obzori, 6(1), 37-48. https://doi.org/10.32728/ $\underline{\text { mo.06.1.2011.03 }}$

Duh, M., Čagran, B., \& Huzjak, M. (2012). Quality and Quantity of Teaching Art Appreciation. Croatian Journal of Education, 14(3), 625-655. 
Duh, M. (2013). Pronalaženje značenja u vizualnoj umjetnosti kao preznačavanja vlastitih govornih konstrukcija. In L. Zaninović Tanay, \& E. R Tanay (Eds.), Sretna djeca: dijete u različitosti izazova (pp. 33-48). Zagreb: Učilište za likovno obrazovanje, kreativnost i dizajn - Studio Tanay.

Duh, M., \& Kač Nemanič, M. (2018). Spremljanje razvoja likovne ustvarjalnosti pri pouku grafičnega oblikovanja. Pedagoška obzorja : časopis za didaktiko in metodiko, 33(1), 31-45.

Duh, M., \& Matrić M. (2015). Creativity Among Gifted and Non-Gifted Students. The New Educational Review, 40 (2), 247-259. https://doi.org/10.15804/tner.2015.40.2.21

Duh, M. Herzog, J., \& Lopert N. (2017). Examining the level of correlations between the factors of artistic creativity in pupils of Slovenian primary schools. Innovative Issues and Approaches in Social Sciences, 10 (3), 21-36. https://doi.org/10.12959/issn.1855-0541. IIASS-2017-no3-art2

Duh, M., \& Zupančič, T. (2013). Likovna apreciacija in metoda estetskega transferja. Revija za elementarno izobraževanje, 6 (4), 71-86.

Ehmann, D. (2005). Using assessment to engage graphic design students in their learning experience. http://www.iml.uts.edu. au/EAC2005/papers/Eh-mann2005.pdf

Ellmers, G. (2006). Reflection and Graphic Design Pedagogy: Developing a Reflective Framework to Enhance Learning in a Graphic Design Tertiary Environment. http:// ro.uow.edu.au/cgi/viewcontent.cgi? article $=1009 \&$ context $=$ creartspapers

Ferjan, T. (2003). Ustvarjalnost učencev -odraz sodobnega pouka. In B. Marentič Požarnik (Ed.), Konstruktivizem v šoli in izobraževanje učiteljev (pp. 122-123). Center za pedagoško izobraževanje Filozofske fakultete in Slovensko društvo pedagogov.

Flint, L. (2014). How creativity came to reside in the land of the gifted (and how to move it into a new neighborhood). Knowledge Quest, 42 (5), 64-69.

Gagné, R. M. (1984). Learning outcomes and their effects: Useful categories of human performance. American Psychologist, 39(4), 377-385. http://apps.fischlerschool.nova.edu/ toolbox/instructionalproducts/8001/EDD8001/SUM12/1984-Gagne.pdf. https://doi. org/10.1037/0003-066X.39.4.377

Herzog, J. (2009). Dejavniki likovne ustvarjalnosti in likovnopedagoško delo. Revija za elementarno izobraževanje, 2(2), 19-31.

Herzog, J. (2013). Razvijanje didaktičnega modela organizacije pedagoške prakse v prvem in drugem triletju osnovne šole pri likovni vzgoji. (Doctoral dissertation). Maribor: Filozofska fakulteta.

Hennessey, B. A., \& Amabile, T. M. (2010). Creativity. Annual Review of Psychology, 61, 569598. https://doi.org/10.1146/annurev.psych.093008.100416

Hewett, T., Czerwinski, M., Terry, M., Tech, G., Nunamaker, J., Candy, L., \& Kules, B. (2005). Creativity Support Tool Evaluation Methods and Metrics. http://www.lisard.com/pdfs/ creativitybook_final.pdf

Howard-Jones, P.A. (2002). A dual-state model of creative cognition for supporting strategies that foster creativity in the classroom. International Journal of Technology and Design Education 12(3), 215-226. https://doi.org/10.1023/A:1020243429353 
Howard, T. J., Culley, S. J., \& Dekoninck, E. (2008). Describing the creative design process by the integration of engineering design and cognitive psychology literature. Design Studies, 29 (2),160-180. https://doi.org/10.1016/j.destud.2008.01.001

Hsiao, H., Liang, Y., \& Lin, T. (2004). A Creative Thinking Teaching Model in a Computer Network Course for Vocational High School Students. World Transactions on Engineering and Technology Education, 3(2), 243-248.

Kač Nemanič, M. (2017). Spremljanje razvoja likovne apreciacije pri pouku grafičnega oblikovanja. Revija za elementarno izobraževanje, 1(2/3), 205-219. https://doi.org/10.18690/18554431.10.2-3.205-219(2017)

Karlavaris, B. (1987). Problemi učnih metod pri likovni vzgoji. Sodobna pedagogika, 38, (3/4), 179-183.

Karlavaris, B., \& Kraguljac, M. (1981). Razvijanje kreativnosti putem likovnog vaspitanja. Institut za pedagoška istraživanja, Prosveta.

Karlavaris, B. (1991). Metodika likovnog odgoja 1. Hofbauer.

Kroflič, R. (2007). Vzgojna vrednost estetske izkušnje. Sodobna pedagogika, 58(3), 12-30.

Kvaščev, R. (1976). Psihologija stvaralaštva. Izdvačko informativni centar studenata / ICS.

Lamagna, C. Z., \& Selim, S. T. (2005). Heterogeneous students, impartial teaching and optimal allocation of teaching methods. General Economics and Teaching. http://129.3.20.41/eps/ get/papers/0503/0503011.pdf

Lau, K. (2009). Creativity Training in Higher Design Education. The Design Journal, 12(2), 153-170. https://doi.org/10.2752/175630609X433111

Littlejohn, S. W., \& Foss, K. A. (2007). Theories of Human Communication. Thomson Learning Inc. Malić, J., \& Mužić, V. (1990). Pedagogija. Školska knjiga.

Meyer, H. (2005). Što je dobra nastava? Erudita.

Pibernik, J., Milčić, D., \& Bota, J. (2010). Pressure toward Creativity: Individual/Group Work in Student Design Competition. In Taura, T. \& Nagai, Y. (Ed.), Proceedings of the 1st International Conference on Design Creativity ICDC 2010 (str. 1-7). The Design Society.

Plucker, J. A., \& Renzulli, J. S. (1999). Psychometric approaches to the Study of Human Creativity. In R.J. Sternberg (Ed.), Handbook of Creativity (pp. 35-62). Cambridge: University Press. https://doi.org/10.1017/CBO9780511807916.005

Pranjić, M. (2005). Didaktika. Povijest, osnove, profiliranje, postupak. Golden marketing Tehnička knjiga.

Spiro, R. J., Vispoel, W., Schmitz, J., Samarapungavan, A., \& Boerger, A. (1987). Knowledge acquisition for application: Cognitive flexibility and transfer in complex content domains. In B. C. Britton (Ed.), Executive control processes (pp. 177-200). Lawrence Erlbaum Associates.

Stevanović, M. (2002). Kreatologija. Express digitalni tisak d.o.o.

Strmčnik, F. (1999). Pouk in njegove funkcije. Sodobna pedagogika, 50, (2), 212-223.

Terhart, E. (2001). Metode poučavanja i učenja: uvod u probleme metodičke organizacije poučavanja i učenja. Educa.

Tomić, A. (2003). Izbrana poglavja iz didaktike. Filozofska fakulteta, Center za pedagoško izobraževanje. 
Trstenjak, A. (1981). Psihologija ustvarjalnosti. Slovenska matica.

Tudor, R. (2008). The Pedagogy of Creativity: Understanding Higher Order Capability Development in Design and Arts Education. http://www.guni-rmies.net

Vygotsky, L. (1978). Mind in Society: The development of higher psychological processes. Harvard University Press.

Williams, A., \& Askland, H. (2012). Assessing Creativity: Strategies and tools to support teaching and learning in architecture and design. Australian Government Office for Learning and Teaching.

\author{
Matjaž Duh \\ Department of Elementary Education \\ Faculty of Education \\ University of Maribor \\ Koroška cesta 160, 2000 Maribor, Slovenia \\ matjaz.duh@um.si
}

\title{
Martina Kač Nemanič
}

Faculty of Design

University of Primorska

Prevale 10, 1236 Trzin, Slovenia

martina.kac.nemanic@fd.si 


\section{Učinkovitost inovativnog didaktičkog pristupa u nastavi grafičkog dizajna}

\section{Sažetak}

Suvremeno obrazovanje omogućuje razvoj kreativnog dizajnerskog izražavanja učenika, ali uloga i značaj didaktičkog pristupa u srednjoj školi nije potpuno proučavana. U radu su prikazani rezultati istraživanja utjecaja inovativnog nastavnog pristupa u pogledu razvoja likovno-dizajnerske kreativnosti i likovne vještine u nastavi grafičkog dizajna. Razlike smo pratili među učenicima 3. godine (17-18 godina) u slovenskim srednjim školama. Potvrdili smo pozitivan učinak $u$ korist eksperimentalne skupine sa sklopom didaktičkih odluka $i$ to kroz ispreplitanje, raznolikost i dinamičnost nastavnih metoda, oblika učenja $i$ didaktičke komunikacije. Pozitivan učinak eksperimentalnog pristupa pokazuje da je moguće uz uvođenje manjih metodičkih izmjena značajno unaprijediti razvoj likovne kreativnosti i likovnih vještina. S uvođenjem temeljnih ideja inovativnog didaktičkog pristupa u osnovnoj školi (Duh, 2004.), potvrdili smo učinkovitosti, fleksibilnost $i$ suptilnost inovacija na razini srednje škole. Također smo ispitivali ulogu spola i stratuma u ukupnom likovnom kreativnom razvoju i utvrdili da je eksperimentalni program pogodan i za djevojčice i dječake, te da se može provoditi $u$ različitim socijalnim sredinama.

Ključne riječi: umjetnička kreativnost; srednja škola; nastavne metode; oblike učenja; didaktička komunikacija. 